\title{
Impacts of the implementation of silvopastoral systems on biodiversity of native plants in a traditional community in the Brazilian Savanna
}

\author{
Isabela Lustz Portela Lima • Aldicir Scariot • \\ Aelton Biasi Giroldo
}

Received: 10 February 2016/ Accepted: 24 June 2016/Published online: 1 July 2016

(C) Springer Science+Business Media Dordrecht 2016

\begin{abstract}
Large-scale commercial cattle ranching is the main driver of deforestation in the world, with several negative environmental and social impacts. To meet the growing demand for animal products, silvopastoral systems (SPS) can be an alternative as they have greater biodiversity and offer more environmental services than conventional cattle ranching systems. This paper aims to describe the implementation of SPS by traditional farmers in a rural settlement in southeastern Brazil, and the impacts on biodiversity of native plants. SPS were implemented by farmers in three selected areas that were cleared with a tractor. The impacts on the community and populations of native plants were estimated through vegetation sampling before and after the implementation of the SPS. Direct observations and semi-structured interviews were conducted to describe the implementation of the system and to understand the criteria employed to spare species, to manage native
\end{abstract}

Electronic supplementary material The online version of this article (doi:10.1007/s10457-016-9981-4) contains supplementary material, which is available to authorized users.

I. L. P. Lima $(\bowtie) \cdot$ A. B. Giroldo

Departamento de Ecologia, Universidade de Brasília, Asa

Norte, Brasília, DF, Brazil

e-mail: isabela_lustz@yahoo.com.br

\section{A. Scariot}

Laboratório de Ecologia e Conservação, Embrapa

Recursos Genéticos e Biotecnologia, Parque Estação

Biológica, Brasília, DF, Brazil plants and the advantages of these systems according to farmers' perceptions. Before the implementation, 1038 trees from 50 species and 29 botanical families were surveyed in the three areas. The tractor cleared on average $72 \%$ of the trees, decreasing the number of trees $\mathrm{ha}^{-1}$ from 692 to 180 and reducing tree richness in $43 \%$. On average, $89 \%$ of the removed trees had diameter ranging from 5 to $10 \mathrm{~cm}$, indicating farmers' preference in sparing the thickest trees. Farmers also spare useful species that have socio-economic importance, such as timber, fruit trees, fodder and medicine. According to the farmers, the advantages of the SPS are the high concentration of useful species, the environmental services provided and the increase in livestock production. The system described has great potential to ensure food security, generating socioeconomic benefits for farmers and contributing to biodiversity conservation.

Keywords Agroforestry system · Cattle $\cdot$ Livestock · Cerrado $\cdot$ Geraizeiros

\section{Introduction}

The increasing demand for animal products has driven agriculture expansion, especially in developing countries, increasing deforestation (Matson et al. 1997; McAlpine et al. 2009; Steinfeld et al. 2006) and converting native areas into simplified and 
homogeneous systems with reduced ecological functions (Lamb et al. 2005; Vitousek et al. 1997). Commercial cattle ranching is the main driver of deforestation in the world, occupying $26 \%$ of the earth's surface and using $33 \%$ of the world's agricultural lands for fodder production (FAO 2009; McAlpine et al. 2009). The activity implies in several negative impacts on biodiversity and peoples livelihoods, leading to species extinction, soil erosion and compaction, water pollution, increased greenhouse gases emissions and displacement of rural populations (FAO 2009; Fearnside 2001; Sawyer 2009; Steinfeld et al. 2006; Steinfeld and Wassenaar 2007).

In Brazil, the rapid agricultural expansion caused impacts on all biomes, especially in the Amazon (Fearnside 1990, 2001; Walker et al. 2009) and Cerrado, the richest savanna in the world, covering $23 \%$ of the Brazilian geographical extension (Aguiar et al. 2004; Klink and Machado 2005; Ribeiro and Walter 2008). Over the past 40 years, half of the original vegetation of the Cerrado has been replaced, mainly with planted pastures and soybean monocultures (MMA, IBAMA 2011). Despite the negative impacts, there is no indication that this trend will decrease, considering the rising demand for animal products, which is already high in developed countries and increasing in developing ones (FAO 2009; McAlpine et al. 2009; Steinfeld et al. 2006). This scenario of rapid biodiversity loss and environmental services disruption calls for innovative and nonconventional land uses that take into account not only economic but also environmental and social aspects.

Silvopastoral systems (SPS) are an environmentally friendly alternative to conventional pastures as they combine in the same area livestock, fodder plants, trees, shrubs, grasses and palm trees (Murgueitio et al. 2011). These systems have greater biodiversity and offer more environmental services than conventional cattle ranching systems (Calle et al. 2009; Haile et al. 2010; Hermuche et al. 2013; McAdam et al. 2007). Besides that, SPS can be more productive (Calle et al. 2012; Dagang and Nair 2003), durable (Steinfeld et al. 2006) and resilient to climate changes (Calle et al. 2009; Murgueitio et al. 2011).

Plants in SPS offer a variety of direct benefits, such as fuelwood, medicine, edible fruits, seeds and flowers, which can be consumed or traded (Bellefontaine et al. 2002; Calle et al. 2012; Foresta et al. 2013). Beyond direct benefits, trees can also mediate ecological processes, increasing soil moisture and fertility, contributing to reduce soil erosion and compaction and to increase carbon sequestration (Jose 2009; Jose and Bardhan 2012; Wedderburn and Carter 1999).

Despite these positive aspects, the impacts of the implementation of SPS on biodiversity have been poorly studied (McAdam et al. 2007; MosqueraLosada et al. 2009). To contribute to fill this gap we used a combination of field inventories with ethnobotanical surveys to assess the impacts of the implementation of SPS on biodiversity of native plants within a traditional community in the Brazilian savanna. We addressed the following questions: (1) what are the effects of the implementation of the SPS on plant richness, diversity and abundance? (2) which species and plant sizes are spared during the implementation of the SPS? and (3) what are the advantages of this system compared to conventional cattle raising systems?

\section{Materials and methods}

Study area

The Americana Settlement is located in Grão Mogol municipality, northern Minas Gerais, southeastern Brazil $\left(16^{\circ} 22^{\prime} \mathrm{S} ; 43^{\circ} 0^{\prime} \mathrm{W}\right)$ (Fig. 1). The local vegetation is a transition between two ecosystems, known as Cerrado and Caatinga, with predominance of Cerrado formations (Dayrell 1998). The climate is Aw (Köppen classification), with dry winters and rainy summers (Peel et al. 2007), average annual rainfall of $800 \mathrm{~mm}$ and average monthly temperature between 18 and $30{ }^{\circ} \mathrm{C}$ (INMET 2015).

The Settlement comprises 76 households, mainly Geraizeiros (77\%) - a traditional population originated from a mixture of indigenous, white and black people, including European colonists and African slaves (Nogueira 2009). The Settlement has 18,922 hectares, divided into legal reserve $(24 \%)$, private properties $(34 \%)$ and a collective management area (42\%) (Carvalho 2012) (Fig. 1). The landscape is classified by local people according to slope, soil, vegetation, uses and management (Carvalho 2013; Dayrell 1998). The highest areas are rangelands used to raise cattle and harvest forest products. The intermediate areas are used to build houses, raise 

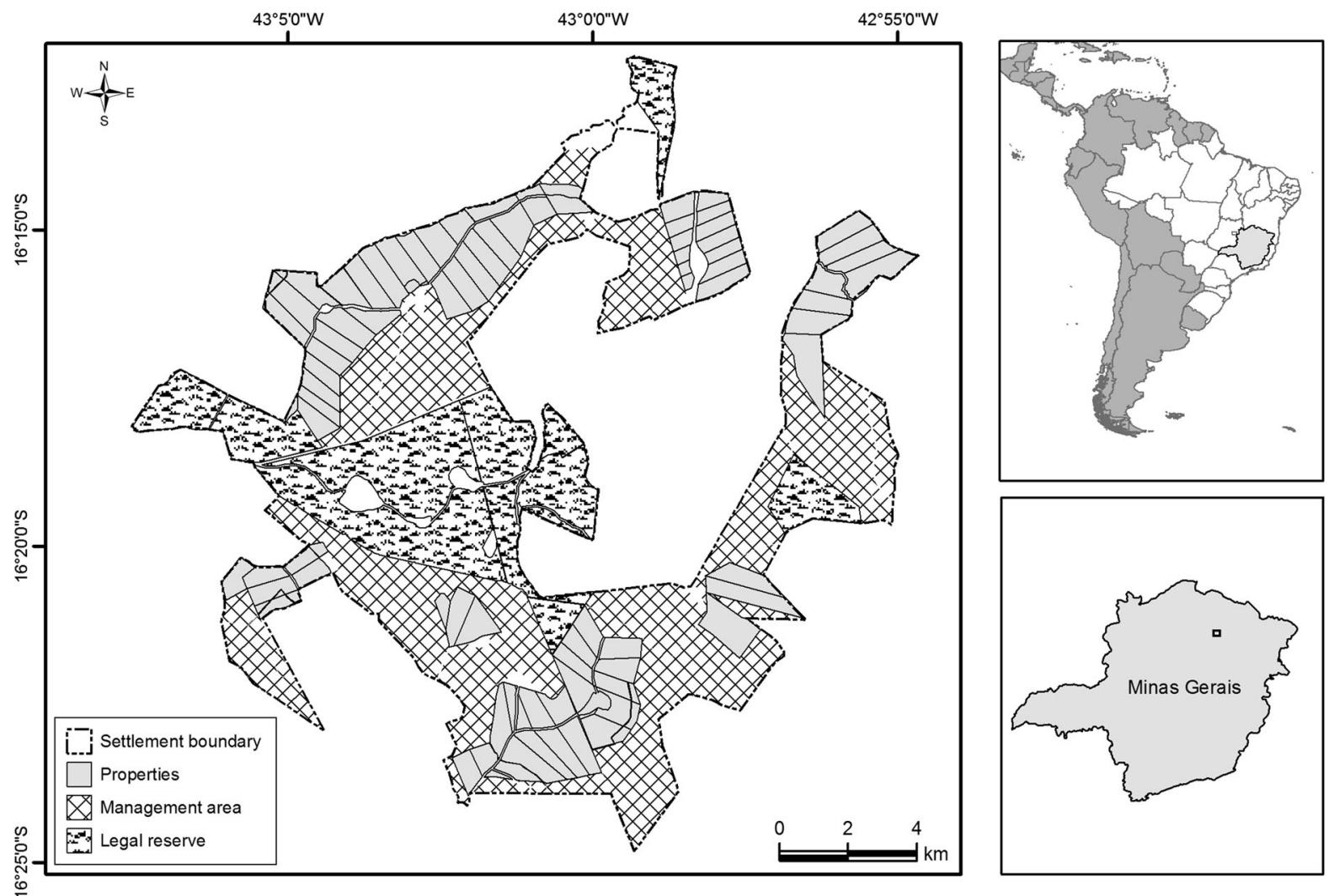

Fig. 1 Americana Settlement in Grão Mogol, northern Minas Gerais state, southeastern Brazil, indicating areas of collective management and legal protection

small animals and cultivate homegardens. The lowest areas are used for agriculture, usually in rotational and diversified systems, historically based on slash and burn (Dayrell 1998; Nogueira 2009).

Implementation of SPS and impacts on native plants biodiversity

SPS were implemented in three areas by Geraizeiros through a participatory methodology (Sithole et al. 2002). The areas (total size $=2.5$ hectares) were cleared with a tractor which cut the herbaceous/shrub layer and thin trees. The thicker and desirable tree species were indicated by the farmer to be spared. After removal of the selected trees, the tractor was used to plow the soil and the African grass Andropogon gayanus Kunth was sown manually.

To estimate the impact of the SPS implementation on biodiversity of native plants, two phytosociological surveys were conducted in each of these three areas, the first one before and the second one after the implementation of the SPS. All trees with diameter at $30 \mathrm{~cm}$ from the ground level $\left(\mathrm{DA}_{30}\right) \geq 5 \mathrm{~cm}$ were sampled in plots of 0.5 hectare each (total size $=1.5$ ha). Sampled trees were identified and measured in $\mathrm{DA}_{30}$ and total height.

Outside the three SPS implemented, a third survey was conducted aiming to estimate the impacts of the tractor on herbs, shrubs and trees with $\mathrm{DA}_{30} \leq 5 \mathrm{~cm}$. For this survey, 12 plots of $9 \mathrm{~m}^{2}$ were allocated, six on plowed areas and six on adjacent non-plowed areas. All plants within these plots were identified and had diameter at soil level and total height measures recorded. Each individual was excavated around the stem to verify whether the plant was originated from seeds or sprouts.

The effects of the SPS implementation in the plant community in the three areas were analyzed in richness, density, basal area, Shannon diversity $\left(\mathrm{H}^{\prime}\right)$ and Pielou equitability $\left(\mathrm{J}^{\prime}\right)$ (Mueller-Dumbois and 
Ellenberg 1974), through the software Fitopac 2.1 (Shepherd 2010). The pared t-test was used to check for significant differences between these parameters within the first and the second surveys. To compare the distribution of diameter class of the tree community and the population structure of the tree species, before (first survey) and after (second survey) the implementation of the SPS, it was performed the KolmogorovSmirnov test, using the software R (R Core and Team 2015). For the third survey, the same phytosociological parameters were analysed and the t-test was used to check for significant differences between plowed and non-plowed areas. Botanical specimens of plants not identified in the field were collected and deposited in the Herbarium CEN-Embrapa Genetic Resources and Biotechnology, in Brasília-DF, for later identification consulting the literature and specialists.

\section{Ethnobotanical surveys}

A complete description of the implementation of the SPS was obtained through semi-structured interviews and direct observations in the three areas, during the implementation process (Bernard 2006). Ethnobotanical surveys were conducted in the field, after clearing the areas, to understand the criteria employed to spare species (Martin 1995).

To understand how Geraizeiros manage native plants, their perception of the ecological processes mediated by native plants and the advantages of SPS when compared with conventional cattle ranching systems, we conducted semi-structured interviews (Bernard 2006) with 14 peasants.

\section{Results and discussion}

Implementation of SPS-impacts on native plants biodiversity

The implementation of SPS requires clearing natural vegetation, which can be done manually or mechanically. The tractor has been widely used by farmers for making the process easier and faster. According to farmers, clearing the vegetation enables grass development and felling trees is not always necessary, but it is inevitable when using a tractor.

Before the implementation of the SPS, a total of 1038 trees from 50 species and 29 botanical families were surveyed in the three areas. Mean tree density was $692 \mathrm{ha}^{-1}(388-1006)$ and mean species richness was 32.3 (25-39). The tractor felled on average $72 \%$ (64.5-77) of the trees. Tree average density therefore decreased by $74 \%$, from 692 to $180.6 \mathrm{ha}^{-1}(\mathrm{t}=3.3$, $\mathrm{df}=2, \mathrm{p}=0.07)$ and average total basal area decreased by $47 \%$, from $2.8 \mathrm{~m}^{2} \mathrm{ha}^{-1}(2.4-3.2)$ to $1.5 \mathrm{~m}^{2} \mathrm{ha}^{-1}(1.2-1.8)(\mathrm{t}=3.94, \mathrm{df}=2, \mathrm{p}=0.05)$.

The SPS implementation caused a reduction in the tree Shannon diversity from 2.7 nats/ind (2.6-2.9) to 2.3 nats/ind (2.0-2.6) $(\mathrm{t}=5.1, \mathrm{df}=2, \mathrm{p}=0.03)$ and a reduction of $43 \%(38.5-48.0 \%)$ in tree richness $(\mathrm{t}=15.4, \mathrm{df}=2, \mathrm{p}<0.01)$ (Table 1). However, these reductions are possibly apparent, because most Cerrado species are resilient to disturbances, sprouting through mobilization of reserves stored in roots or stem (Bond and Midgley 2001; Dayamba et al. 2011; Miranda et al. 2002; Neke et al. 2006), as demonstrated in the third survey comparing plowed and non-plowed areas. Despite the significant reduction in plant density in the plowed areas $(t=5.09, \mathrm{df}=8.40, \mathrm{p}<0.01)$, plant richness $(t=0.95$, df $=8.44, p=0.37)$, Shannon diversity $\quad(t=0.63, \quad \mathrm{df}=7.59, \quad \mathrm{p}=0.55) \quad$ and equitability $(\mathrm{t}=1.90$, $\mathrm{df}=6.42, \mathrm{p}=0.10)$ were not statistically different in plowed and non-plowed plots, indicating the great resprouting capacity of the species after mechanical clearing (Table 1).

On average, $89.2 \%(88-94 \%)$ of the removed trees had diameter $\left(\mathrm{DA}_{30}\right)$ ranging from 5 to $10 \mathrm{~cm}$, indicating the preference of the peasants for removing the thinner tress and sparing the thickest ones. The distributions of diametric classes before and after removal of the trees are statistically different (Kolmogorov-Smirnov; $\quad \mathrm{D}_{\text {area1 }}=0.28, \quad \mathrm{D}_{\text {area2 }}=0.44$, $\left.\mathrm{D}_{\text {area3 }}=0.31, \mathrm{p}<0.01\right)$, with more pronounced reduction in the smaller classes (Fig. 2). Diameter class distribution of $18.5 \%$ of the species sampled were significantly modified after mechanical clearing $(\mathrm{D}=0.34, \mathrm{p}<0.01)$ (Table 2). Additionally, 19 tree species sampled in the survey before mechanical clearing were not sampled after.

Besides prioritizing cutting down trees with smaller diameter, farmers purposefully spare specific species_-generally trees providing timber, fruits, fodder and medicine. Among the 31 tree species spared in the three areas, 18 are used for timber $(58 \%), 13$ are medicinal $(41.9 \%)$, four are fruit trees $(12.9 \%)$, three are fodder $(9.6 \%)$ and only three do not belong to any use category (Table 2; Fig. 3). 
Table 1 Phytosociological parameters for trees with $\mathrm{DA}_{30} \geq 5 \mathrm{~cm}$, surveyed before and after the implementation of SPS; and herbs, shrubs and trees with $\mathrm{DA}_{30} \leq 5 \mathrm{~cm}$ surveyed in plowed and non-plowed areas

\begin{tabular}{|c|c|c|c|c|}
\hline \multirow[t]{2}{*}{ Parameter } & \multicolumn{2}{|c|}{ Trees $\mathrm{DA}_{30} \geq 5 \mathrm{~cm}$} & \multicolumn{2}{|c|}{ Herbs, shrubs and trees $\mathrm{DA}_{30} \leq 5 \mathrm{~cm}$} \\
\hline & Before & After & Non-plowed & Plowed \\
\hline Number of individuals sampled & 1,038 & 271 & 582 & 378 \\
\hline Richness & 50 & 31 & 88 & 85 \\
\hline Botanical families & 29 & 20 & 39 & 43 \\
\hline Density & $692 \mathrm{ha}^{-1}$ & $181 \mathrm{ha}^{-1}$ & $5.4 \mathrm{~m}^{-2}$ & $3.5 \mathrm{~m}^{-2}$ \\
\hline Shannon-Wiener index & 3.0 & 2.7 & 3.8 & 3.9 \\
\hline Equitability & 0.76 & 0.78 & 0.9 & 0.9 \\
\hline
\end{tabular}
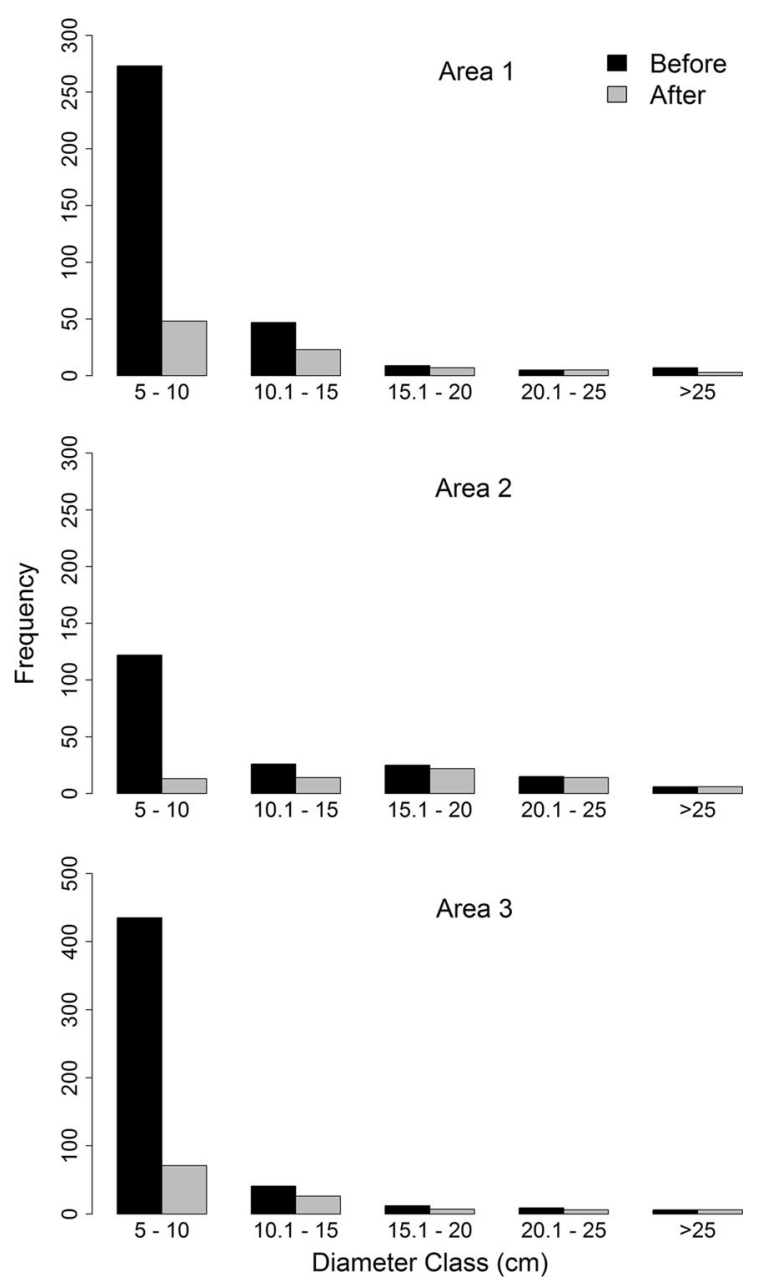

Fig. 2 Size class distributions of the tree community in three areas before and after clearing for the implementation of silvopastoral systems
Among the species with highest density before clearing the areas, the lowest clearing rates were for Caryocar brasiliense, with a mean spare rate of $71.2 \%$ and Bowdichia virgilioides, with a mean spare rate of $55.6 \%$ (Fig. 3; Table 2). Both species have high socio-economic importance for farmers. $C$. brasiliense, whose felling is illegal, produces the main forest product in the region-fruits widely used and sold in the regional market (Oliveira and Scariot 2010). B. virgilioides has high quality timber, used mainly for furniture making (Almeida et al. 1998).

To complete the SPS implementation, the grass is manually sown after the clearing, in the beginning of the rainy season. Generally, farmers plant only two grass species-Andropogon gayanus and Brachiaria decumbens - both of African origin. African grasses have higher productivity than the native ones due to high photosynthetic capacity, higher seed production and faster germination (Pivello et al. 1999). Furthermore, they tolerate fire and grazing (D'Antonio and Vitousek 1992). Between 3 and 6 months after germination, the grass reaches around $60 \mathrm{~cm}$ of height; when pastures are ready to receive livestock for grazing.

Management and advantages of SPS according to farmers' perceptions

A remarkable feature of SPS implemented in the Americana Settlement is the high number of sprouts from different species. Of the 961 herbs, shrubs and trees with $\mathrm{DA}_{30} \leq 5 \mathrm{~cm}$ surveyed in plowed and nonplowed Cerrado plots, 93.6 and $85.7 \%(\mathrm{t}=1.15$, 
Table 2 Plant uses of native tree species spared in SPS; density before and after clearing the areas and the results of the Kolmogorov-Smirnov test (D), indicating differences in the population structures before and after the implementation of the system

\begin{tabular}{|c|c|c|c|c|c|c|}
\hline Species & $\begin{array}{l}\text { Popular } \\
\text { names }\end{array}$ & Use category & $\begin{array}{l}\text { Density }\left(\mathrm{ha}^{-1}\right) \\
\text { before }\end{array}$ & $\begin{array}{l}\text { Density } \\
\left(\mathrm{ha}^{-1}\right) \text { after }\end{array}$ & $\begin{array}{l}\text { Density } \\
\text { reduction }(\%)\end{array}$ & D test \\
\hline $\begin{array}{l}\text { Acosmium } \\
\text { dasycarpum }\end{array}$ & Unha-danta & $\begin{array}{l}\text { Medicinal, timber and } \\
\text { fodder }\end{array}$ & 46.7 & 6.0 & 87.1 & $0.35 ; \mathrm{p}=0.27$ \\
\hline Annona crassiflora & $\begin{array}{l}\text { Panã/ } \\
\text { Araticum }\end{array}$ & Fruit tree & 5.3 & 4.0 & 25.0 & - \\
\hline $\begin{array}{l}\text { Aspidosperma } \\
\text { macrocarpon }\end{array}$ & $\begin{array}{l}\text { Chapéu-de- } \\
\text { couro }\end{array}$ & Medicinal & 0.7 & 0.7 & 0 & - \\
\hline $\begin{array}{c}\text { Aspidosperma } \\
\text { tomentosum }\end{array}$ & $\begin{array}{l}\text { Pereiro-de- } \\
\text { chapada }\end{array}$ & Timber & 11.3 & 4.0 & 64.7 & $0.37 ; \mathrm{p}=0.56$ \\
\hline $\begin{array}{l}\text { Astronium } \\
\text { fraxinifolium }\end{array}$ & Gonçalo & Timber and medicinal & 18.0 & 3.3 & 81.5 & - \\
\hline B. virgilioides & $\begin{array}{l}\text { Sucupira- } \\
\text { branca }\end{array}$ & Timber & 72.0 & 40.0 & 44.4 & $0.18 ; p=0.14$ \\
\hline C. brasiliense & Pequi & Fruit tree & 39.3 & 28.0 & 28.8 & $0.14 ; p=0.68$ \\
\hline $\begin{array}{l}\text { Dalbergia } \\
\text { miscolobium }\end{array}$ & Cabiúna & Timber & 30.0 & 6.0 & 80.0 & $0.49 ; \mathrm{p}=0.05$ \\
\hline Eriotheca gracilipes & $\begin{array}{c}\text { Embiruçu- } \\
\text { paulista }\end{array}$ & Timber & 89.3 & 15.3 & 82.8 & $0.41 ; \mathrm{p}=0.003^{*}$ \\
\hline Erythroxylum sp1 & \# & \# & 0.7 & 0.7 & 0 & - \\
\hline Eugenia dysenterica & Cagaita & Fruit tree & 8.7 & 1.3 & 84.7 & $0.53 ; \mathrm{p}=0.69$ \\
\hline Guapira noxia & Pau-de-urubu & Timber and fodder & 23.3 & 2.7 & 88.6 & $0.77 ; \mathrm{p}=0.027^{*}$ \\
\hline $\begin{array}{l}\text { Handroanthus } \\
\text { ochraceus }\end{array}$ & Ipê-amarelo & Timber and medicinal & 9.3 & 1.3 & 85.7 & $0.85 ; \mathrm{p}=0.15$ \\
\hline $\begin{array}{l}\text { Hymenaea } \\
\text { stigonocarpa }\end{array}$ & Jatobá & $\begin{array}{l}\text { Timber; medicinal } \\
\text { and fruit tree }\end{array}$ & 23.3 & 5.3 & 77.2 & $0.46 ; p=0.12$ \\
\hline Hyptidendron sp1 & $\begin{array}{l}\text { Alecrim-de- } \\
\text { tabuleiro }\end{array}$ & Timber & 10.0 & 1.3 & 86.7 & $0.36 ; p=0.97$ \\
\hline Lafoensia pacari & Pacari & Medicinal & 14.7 & 3.3 & 77.3 & $0.28 ; \mathrm{p}=0.9$ \\
\hline Licania sp1 & \# & $\#$ & 0.7 & 0.7 & 0 & - \\
\hline $\begin{array}{l}\text { Machaerium } \\
\text { opacum }\end{array}$ & Jacarandá & Timber & 57.3 & 7.3 & 87.2 & $0.42 ; \mathrm{p}=0.05^{*}$ \\
\hline Magonia pubescens & Tingui & Timber & 10.7 & 1.3 & 87.5 & - \\
\hline $\begin{array}{l}\text { Plathymenia } \\
\text { reticulata }\end{array}$ & Vinhático & Timber & 6.0 & 4.0 & 33.3 & $0.27 ; p=0.94$ \\
\hline Plenckia populnea & $\begin{array}{l}\text { Mangabeira- } \\
\text { brava }\end{array}$ & Timber & 4.7 & 1.3 & 71.5 & $0.57 ; \mathrm{p}=0.69$ \\
\hline Qualea grandiflora & Pau-terrão & Timber and medicinal & 104.7 & 25.3 & 75.8 & $0.37 ; \mathrm{p}<0.001 *$ \\
\hline Qualea parviflora & Pau-terrinha & Timber & 22.7 & 4.7 & 79.4 & $0.56 ; p=0.05^{*}$ \\
\hline Roupala montana & $\begin{array}{l}\text { Espinheira- } \\
\text { santa }\end{array}$ & Medicinal & 15.3 & 2.0 & 87.0 & $0.21 ; \mathrm{p}=0.99$ \\
\hline $\begin{array}{l}\text { Schefflera } \\
\quad \text { macrocarpa }\end{array}$ & Violeiro & Fodder & 4.0 & 0.7 & 83.3 & $0.8 ; p=0.66$ \\
\hline $\begin{array}{l}\text { Sclerolobium cf. } \\
\text { aureum }\end{array}$ & Pau-fede & Timber and medicinal & 2.0 & 1.3 & 33.5 & $0.66 ; p=0.66$ \\
\hline $\begin{array}{l}\text { Strychnos } \\
\text { pseudoquina }\end{array}$ & $\begin{array}{l}\text { Quina-de- } \\
\text { papagaio }\end{array}$ & Medicinal & 5.3 & 2.0 & 62.5 & $0.62 ; p=0.36$ \\
\hline $\begin{array}{l}\text { Stryphnodendron } \\
\text { adstringens }\end{array}$ & Barbatimão & Medicinal & 16.0 & 2.7 & 83.3 & $0.21 ; p=0.99$ \\
\hline
\end{tabular}


Table 2 continued

\begin{tabular}{llllllc}
\hline Species & $\begin{array}{l}\text { Popular } \\
\text { names }\end{array}$ & Use category & $\begin{array}{l}\text { Density }\left(\mathrm{ha}^{-1}\right) \\
\text { before }\end{array}$ & $\begin{array}{l}\text { Density } \\
\left(\mathrm{ha}^{-1}\right) \text { after }\end{array}$ & $\begin{array}{l}\text { Density } \\
\text { reduction }(\%)\end{array}$ & D test \\
\hline $\begin{array}{c}\text { Stryphnodendron } \\
\text { polyphyllum }\end{array}$ & $\#$ & $\#$ & 0.7 & 0.7 & 0 & - \\
$\begin{array}{l}\text { Tabebuia aurea } \\
\begin{array}{c}\text { Terminalia } \\
\text { argentea }\end{array}\end{array}$ & Caraíba & Timber & 5.3 & 2.0 & 62.5 & $0.62 ; \mathrm{p}=0.36$ \\
\hline
\end{tabular}

* Indicates significant differences $(\mathrm{p}<0.05)$; \# indicates that the species has no known popular name or use; - indicates insufficient data for the Kolmogorov-Smirnov test

df $=9.9, p=0.27)$, respectively, were originated from sprouts and not from seeds. According to farmers, sprouts have a key role in the system. Besides feeding livestock, especially in the dry season when grass availability is lower, sprouts help to improve the soil, retaining moisture and preventing compaction. Excess of sprouts, however, can be harmful because it prevents the development of recently sown grass. Thus, farmers remove the excess of sprouts through weeding, usually before the rainy season, after the dispersal of grass seeds and cattle grazing. During weeding, sprouts of species that have no direct benefit for farmers are removed and sprouts of useful species such as timber, fruit trees and medicinal plants are selected and spared.

According to the farmers, one of the advantages of the SPS is the high concentration of useful species which provide products such as fodder, timber, firewood, fruits and medicinal plants. These forest products play a fundamental role in complementing agricultural activities, contributing to improve livelihood and generate income (Arnold and Pérez 1998; Bharucha and Pretty 2010; Campbell and Luckert 2002; Gunatilake et al. 1993; Shackleton et al. 2011).

Other advantages are the environmental services these systems provide and the increase in livestock production. Trees in SPS help to prevent soil erosion and compaction and improve nutrient cycling. They also provide shade, which helps to retain soil moisture, maintaining grasses green for a long time. The cattle, besides diversifying their diet by feeding on branches, fruits, flowers and shoots of native species, also benefit from the shade of the trees, reducing stress and energy waste (Calle et al. 2009). In this sense, SPS can be more productive and profitable than conventional cattle ranching systems, showing a great potential to contribute to poverty reduction in rural areas (Calle et al. 2012) and improve food security (Herrero et al. 2010).

\section{Conclusions and implications for conservation}

Less intensive and small-scale production systems generally integrate agriculture and cattle raising with forest management, using resources efficiently, generating income to smallholder farmers, providing food for the poor and maintaining environmental services (Herrero et al. 2010; Perfecto and Vandermeer 2010). An example of this are the SPS of Geraizeiros, practiced in the Brazilian Savanna of northern Minas Gerais.

This system turns out to be a viable alternative to agricultural intensification as it is able to reconcile production with biodiversity conservation. Besides the reduction in native plants biodiversity, the system maintains high concentration of useful species, providing several environmental services and increasing livestock production.

Thicker and useful tree species such as those providing timber, fruits, fodder and medicine are generally spared from clearing and the products derived from them can be consumed or traded, generating socioeconomic benefits and contributing to local livelihoods (Bellefontaine et al. 2002; Calle et al. 2012; Foresta et al. 2013). Trees in SPS can also mediate ecological processes, increasing soil moisture and fertility, contributing to reduce soil erosion and compaction and to increase carbon sequestration (Jose 2009; Jose and Bardhan 2012; Wedderburn and Carter 1999).

For these reasons, the SPS studied can serve as templates to a more equitable and environmentally friendly cattle raising system, which is capable to 

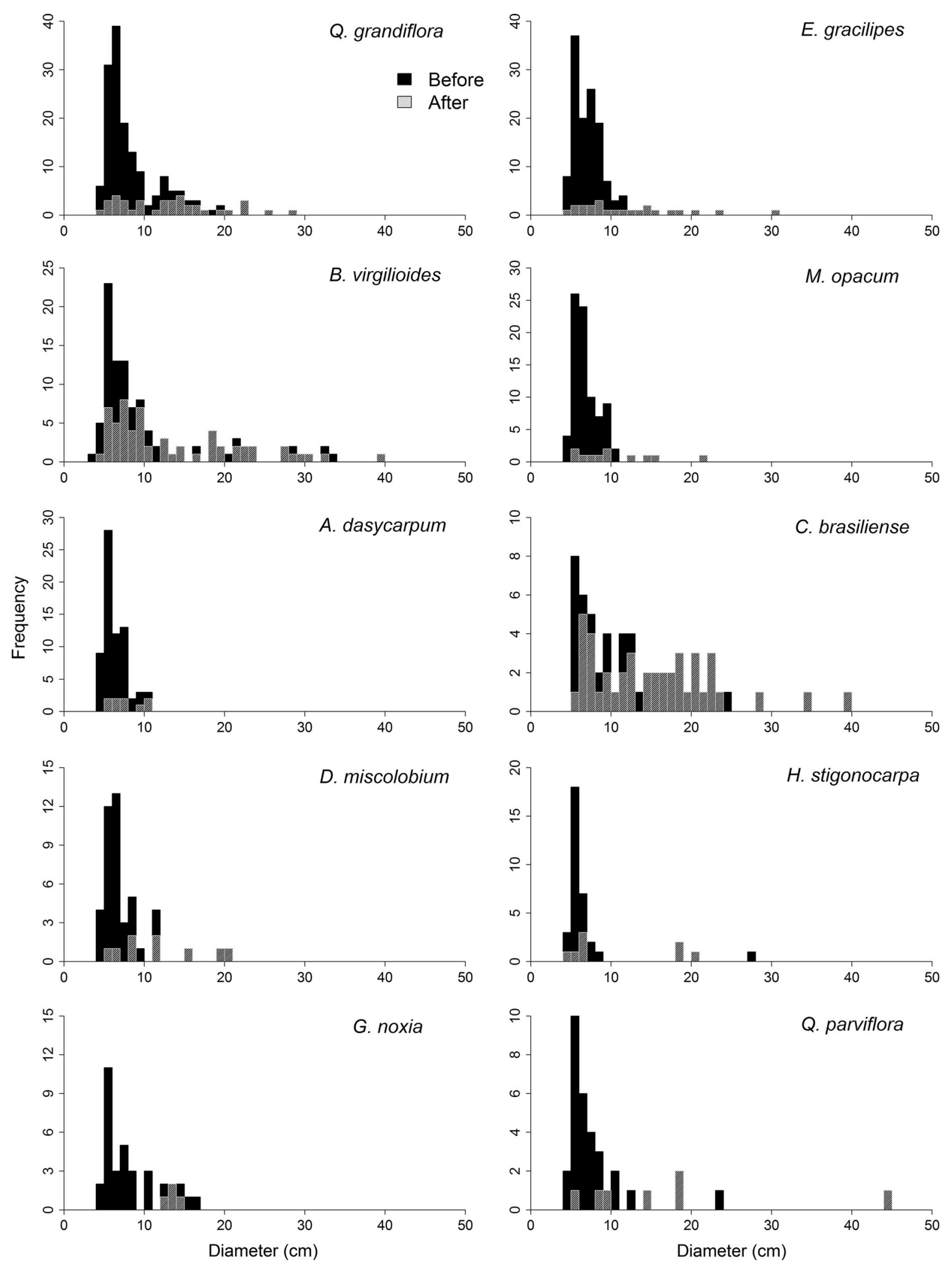
4Fig. 3 Number of trees by diameter class of the 10 most abundant species, before and after clearing the areas for the implementation of silvopastoral systems

ensure food security, meet the growing demand for food and contribute to biodiversity conservation and poverty alleviation in rural areas in the tropics.

Acknowledgments This research was supported by Funbio/ TFCA, CNPq and CAPES grants and fellowships. Embrapa (Cenargen) provided technical and logistic support. Juarez P. Amaral, José M. Mendonça, Nilton F. Barbosa, João Benedito Pereira, Pedro Vasconcelos and Elisa Pereira helped with fieldwork. We acknowledge all farmers of the Americana Settlement, especially Maria Elei N. Souza, Aparecido A. Souza, João Altino Neto and Cristovino F. Neto. We appreciate the valuable contributions by Miguel Alexiades and the revision by Bruno Ubiali.

\section{References}

Aguiar LMS, Machado LM, Filho JM (2004) A diversidade biológica do Cerrado. In: Aguiar LMS, Camargo AJA (eds) Cerrado: ecologia e caracterização. Embrapa Informação Tecnológica, Brasília, pp 17-40

Almeida SP, Proença CEB, Sano SM, Ribeiro JF (1998) Cerrado: espécies vegetais úteis. Empresa Brasileira de Pesquisa Agropecuária, Centro de Pesquisa Agropecuária dos Cerrados, Ministério da Agricultura e do Abastecimento

Arnold JEM, Pérez MR (1998) The role of non-timber forest products in conservation and development. In: Wollenberg E, Ingles A (eds) Incomes from the forest: methods for the development and conservation of forest products for local communities. Center for International Forestry Research (CIFOR), Bogor

Bellefontaine R, Petit S, Pain-Orcet M, Deleporte P, Bertault J (2002) Trees outside forests: towards a better awareness. FAO, Rome

Bernard RH (2006) Research methods in Antropology: qualitative and quantitative approachs. Altamira, Oxford

Bharucha Z, Pretty J (2010) The roles and values of wild foods in agricultural systems

Bond WJ, Midgley JJ (2001) Ecology of sprouting in woody plants: the persistence niche. Trends Ecol Evol 16:45-51

Calle A, Montagnini F, Zuluaga AF (2009) Farmeŕs perceptions of silvopastoral system promotion in Quindío, Colombia. Bois For Trop 300:79-94

Calle Z, Murgueitio E, Chará J (2012) Intensive silvopastoral systems integrate forestry, sustainable cattle ranching and landscape restoration. Unasylva 239:11-20

Campbell BM, Luckert MK (2002) Towards understanding the role of forests in rural livelihoods. In: Campbell BM, Luckert MK (eds) Uncovering the hidden harvest: valuation methods for woodland and forest resources. Earthscan, London

Carvalho ISH (2012) Assentamento Americana e Grupo Agroextrativista do Cerrado: uma experiência agroecológica no Norte de Minas. Instituto Sociedade População e Natureza, Brasília

Carvalho ISH (2013) Campesinato e biodiversidade no Cerrado: um estudo sobre o Assentamento Americana (Grão Mogol MG) à luz da agroecologia. Universidade Estadual de Campinas, Campinas-SP, Tese de Doutorado, Instituto de Filosofia e Ciências Humanas

Dagang AK, Nair PKR (2003) Silvopastoral research and adoption in Central America: recent findings and recommendations for future directions. Agrofor Syst 59:149-155

D’Antonio CM, Vitousek PM (1992) Biological invasions by exotic grasses, the grass/fire cycle, and global change. Annu Rev Ecol Syst 23:63-87

Dayamba S, Savadogo P, Sawadogo L, Zida D, Tiveau D, Oden P (2011) Dominant species' resprout biomass dynamics after cutting in the Sudanian Savanna-Woodlands of West Africa: long term effects of annual early fire and grazing. Ann For Sci 68:555-564

Dayrell CA (1998) Geraizeiros e biodiversidade no Norte de Minas: a contribuição da agroecologia e da etnoecologia nos estudos dos agroecossistemas tradicionais. Universidade Internacional de Andalucia, Espanha, Dissertação de Mestrado, Agroecologia e Desenvolvimento Rural Sustentável, p 193

FAO (2009) The State of Food and Agriculture: livestock in the balance. FAO, Roma

Fearnside PM (1990) The rate and extent of deforestation in Brazilian Amazonia. Environ Conserv 17:213-226

Fearnside PM (2001) Soybean cultivation as a threat to the environment in Brazil. Environ Conserv 28:23-38

Foresta H, Somarriba E, Temu A, Boulanger D, Feuilly H, Gauthier M (2013) Towards the assessment of trees outside forests: a thematic report prepared in the framework of the global forest resources assessment. FAO, Rome

Gunatilake HM, Senaratne DMAH, Abeygunawardena P (1993) Role of non-timber forest products in the economy of peripheral communities of Knuckles National Wilderness area of Sri Lanka: a farming systems approach. Econ Bot 47:275-281

Haile SG, Nair VD, Nair PKR (2010) Contribution of trees to carbon storage in soils of silvopastoral systems in Florida, USA. Glob Change Biol 16:427-438

Hermuche PM, Vieira DLM, Sano EE (2013) Modeling tree cover changes in a pasture-dominated landscape by adopting silvopastoral practices in a dry forest region in Central Brazil. Agrofor Syst 87:881-890

Herrero M, Thornton PK, Notenbaert AM, Wood S, Msangi S, Freeman HA, Bossio D, Dixon J, Peters M, van de Steeg J, Lynam J, Parthasarathy Rao P, Macmillan S, Gerard B, McDermott J, Seré C, Rosegrant M (2010) Smart investments in sustainable food production: revisiting mixed crop-livestock systems. Science 327:822-825

INMET (2015) Instituto Nacional de Meteorologia: Estação Climatólogica de Salinas. INMET/MAPA, Brasília

Jose S (2009) Agroforestry for ecosystem services and environmental benefits: an overview. Agrofor Syst 76:1-10

Jose S, Bardhan S (2012) Agroforestry for biomass production and carbon sequestration: an overview. Agrofor Syst 86:105-111

Klink CA, Machado RB (2005) Conservation of the Brazilian Cerrado. Conserv Biol 19:707-713 
Lamb D, Erskine PD, Parrotta JA (2005) Restoration of degraded tropical forest landscapes. Science 310:1628-1632

Martin GL (1995) Ethnobotany: a people and plants conservation manual. Chapman \& Hall, London

Matson PA, Parton WJ, Power AG, Swift MJ (1997) Agricultural intensification and ecosystem properties. Science 277:504-509

McAdam JH, Sibbald AR, Teklehaimanot Z, Eason WR (2007) Developing silvopastoral systems and their effects on diversity of fauna. Agrofor Syst 70:81-89

McAlpine CA, Etter A, Fearnside PM, Seabrook L, Laurance WF (2009) Increasing world consumption of beef as a driver of regional and global change: a call for policy action based on evidence from Queensland (Australia), Colombia and Brazil. Glob Environ Change 19:21-33

Miranda HS, Bustamante MMC, Miranda AC (2002) The fire factor. In: Oliveira PS, Marquis RJ (eds) The Cerrados of Brazil: ecology and natural history of a neotropical Savanna. Columbia University Press, New York, pp 51-68

MMA, IBAMA (2011) Monitoramento do bioma Cerrado 2009-2010. Relatório Técnico-Monitoramento do desmatamento dos biomas brasileiros por satélite, Brasília

Mosquera-Losada MR, Rodríguez-Barreira S, López-Díaz ML, Fernández-Núñez E, Rigueiro-Rodríguez A (2009) Biodiversity and silvopastoral system use change in very acid soils. Agric Ecosyst Environ 131:315-324

Mueller-Dumbois D, Ellenberg H (1974) Aims and methods of vegetation ecology. Wiley, New York

Murgueitio E, Calle Z, Uribe F, Calle A, Solorio B (2011) Native trees and shrubs for the productive rehabilitation of tropical cattle ranching lands. For Ecol Manage 261:1654-1663

Neke KS, Owen-Smith N, Witkowski ETF (2006) Comparative resprouting response of Savanna woody plant species following harvesting: the value of persistence. For Ecol Manage 232:114-123

Nogueira MCR (2009) Gerais a dentro e a fora: identidade e territorialidade entre Geraizeiros do Norte de Minas Gerais. Universidade de Brasília, Brasília, DF, Tese de Doutorado, Departamento de Antropologia, p 233

Oliveira WL, Scariot A (2010) Boas Práticas de Manejo para o Extrativismo Sustentável do Pequi. Embrapa Recursos Genéticos e Biotecnologia, Brasília

Peel MC, Finlayson BL, McMahon TA (2007) Updated world map of the Köppen-Geiger climate classification. Hydrol Earth Syst Sci 11:1633-1644
Perfecto I, Vandermeer J (2010) The agroecological matrix as alternative to the land-sparing/agriculture intensification model. Proc Natl Acad Sci USA 107:5786-5791

Pivello VR, Shida CN, Meirelles S (1999) Alien grasses in Brazilian savannas: a threat to the biodiversity. Biodivers Conserv 8:1281-1294

R Core Team (2015) R: a language and environment for statistical computing. R foundation for statistical computing, Vienna

Ribeiro JF, Walter BM (2008) As principais fitofisionomias de Cerrado. In: Sano SM, Almeida SP, Ribeiro JF (eds) Cerrado: ecologia e flora. Embrapa Informação Tecnológica, Embrapa Cerrados, Planaltina, DF, pp 151-212

Sawyer DR (2009) Políticas públicas e impactos socioambientais no Cerrado. In: Galinkin AL, Pondaag MCM (eds) Capacitação de Lideranças do Cerrado. TechnoPolitik, Brasília

Shackleton S, Delang C, Angelsen A (2011) From subsistence to safety nets and cash income: exploring the diverse values of non-timber forest products for livelihoods and poverty alleviation. In: Shackleton S, Shackleton C, Shanley P (eds) Non-timber forest products in the global context. Springer, Berlin Heidelberg, pp 55-81

Shepherd GJ (2010) Fitopac 2.1: Manual do Usuário. Unicamp, Campinas

Sithole B, Frost P, Veeman TS (2002) Participatory methods for exploring livelihood values derived from forests: potential and limitations. In: Campbell BM, Luckert MK (eds) Uncovering the hidden harvest: valuation methods for woodland and forest resources. Earthscan, London

Steinfeld H, Wassenaar T (2007) The role of livestock production in carbon and nitrogen cycles. Annu Rev Environ Resour 32:271-294

Steinfeld H, Gerber P, Wassenaar T, Castel V, Rosales M, Haan C (2006) Livestock's Long Shadow: environmental issues and options. FAO, Roma

Vitousek PM, Mooney HA, Lubchenco J, Melillo JM (1997) Human domination of Earth's ecosystems. Science 277:494-499

Walker R, Browder J, Arima E, Simmons C, Pereira R, Caldas M, Shirota R, Zen Sd (2009) Ranching and the new global range: Amazônia in the 21st century. Geoforum 40:732-745

Wedderburn ME, Carter J (1999) Litter decomposition by four functional tree types for use in silvopastoral systems. Soil Biol Biochem 31:455-461 